Teknomekanik

Vol.3, No.1, May 2020, pp. 17 22

e-ISSN: $2621-8720$ p-ISSN: 2621-9980

\title{
Design of Hybrid Hull Ship by B-NINE TEAM to The National Unmanned Fast Boat Contest 2019
}

\author{
Salmat, Arya Zulhendrik, Muhammad Iqbal Iski, Arifin Adli and Aulia Zulkarnaen Nasty \\ Jurusan Teknik Mesin, Fakultas Teknik, Universitas Negeri Padang, Indonesia
}

\section{Article Info}

Article history:

Received Jan $21^{\text {th }}, 2020$

Revised Feb 26 th 2020

Accepted April $19^{\text {th }}, 2020$

\section{Keywords:}

\section{KKCTBN}

Hybrid Hull

Resistance

Engine Power

$x$-bow

\section{Corresponding Author:}

Salmat,

Jurusan Teknik Mesin, Fakultas Teknik, Universitas Negeri Padang

Jln. Prof. Dr. Hamka Air Tawar, Padang (25131), Sumatera Barat, Indonesia

Email:salmat1710@gmail.com

\section{INTRODUCTION}

Indonesian is a maritime country, where two thirds of the area is sea. The President of Indonesian Joko Widodo initiated new reform for indonesian maritime sectors with a comprehensive concept of "world maritime axis" [1]. The Unmanned Fast Boat Contest 2019 is an event to discover college interests and talents about ships and a place to hone and develop college competitions. College as the younger generation needs to be instilled with a sense of awareness to maintain the sovereignty of the Republic of Indonesian. Often cases of illegal fishing in Indonesian oceans by fishermen from other countries must be a problem for Indonesian. Indonesian need fast, stable and strong ship technology against waves in Indonesian ocean. Ships as pbservers and guards of Indonesian oceans are urgently needed by the Ministry of Marine Affairs and Fisheries in guarding and monitoring Indonesian ocean from foreign fishermen. B-NINE TEAM from Universitas Negeri Padang is very interested and interested in designing a remote-control ship to participate in KKCTBN 2019 based on illegal fishing cases that occur and ships through library studies and analysis of ship models using computer simulations.

Concept of a ship that is designed is a ship to protect and monitor Indonesian ocean. Therefore, a ship must be fast, stable and resilient to waves in Indonesian ocean. The shape of hull used will affect resistance, speed and stability of ship [2]. Reviewed from a number of hulls, it is divided into two types, namely monohull and catamaran. Safehaven Marine developed a hybrid monohull and catamaran for ships with high speed and good stability, at the front of shp using V-hull type with a wave piercing bow and at the rear ship using a catamaran hull type with an asymmetrical V-type with flat inside [3]. Safehaven marine ship model becomes a reference in ship hull design.

\section{METHOD}

Ship design method uses ship comparison method and trial-error to determine shape of hull to be used and numerical experiments are carried out. Design of hull model starts with planning the main size chosen as a comparison ship, then several shapes are made of catamaran hull used on rare hull and then tested using 
computer simulations. Initial stage is starting to make a ship model and then it is analyzed using computer simulations to get an analysis of resistance, stability and seakeeping ship. Ship model were created using software Solidworks and Maxsurf and computer simulation analysis using Software Maxsurf.

\subsection{Hull Model Optimization Parameters}

The type of ship that is referenced in make ship models is type patrol vessel developed by Safehaven Marine with a hybrid hull type. Main ship size used are as follows:

\begin{tabular}{llll} 
Tariable & Table 1 : Main Size Model Ship & \\
\hline LOA & Description & $\begin{array}{l}\text { Safehaven } \\
\text { Dimension }\end{array}$ & $\begin{array}{l}\text { KKCTBN 2019 } \\
\text { Dimension }\end{array}$ \\
\hline Lwl & Length Overall & $24 \mathrm{~m}$ & $0.80 \mathrm{~m}$ \\
$\mathrm{~B}$ & Length Waterline & $23.7 \mathrm{~m}$ & $0.79 \mathrm{~m}$ \\
$\mathrm{H}$ & Beam & $5.4 \mathrm{~m}$ & $0.05 \mathrm{~m}$ \\
$\mathrm{~T}$ & Depth & $7.2 \mathrm{~m}$ & $0.24 \mathrm{~m}$ \\
\hline
\end{tabular}

Variable parameter used in determining ship design is variation of hull shape of catamaran $\mathrm{V}$ Asymmetric inside flat type. There are two types of modifications applied, namely modification $U$ Asymmetric type and modification U Symmetric which can be seen in Figure 1.

(a)

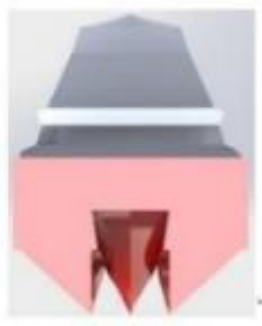

(b)

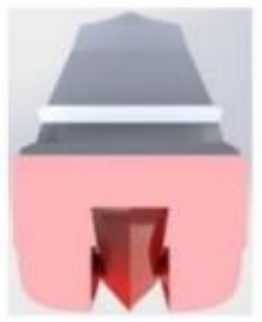

(b)

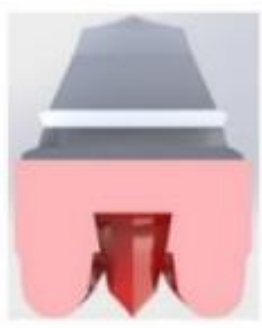

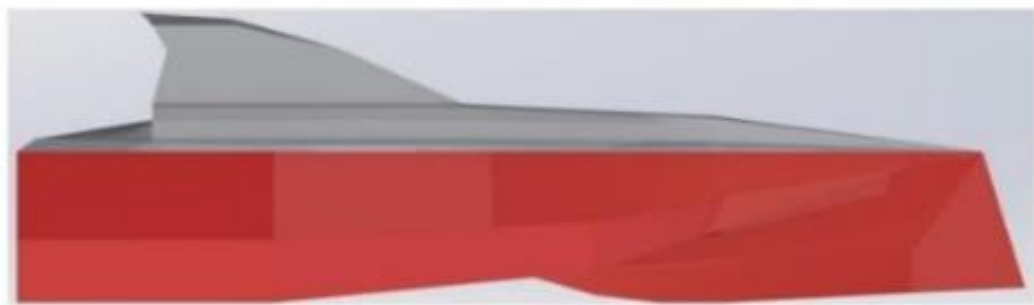
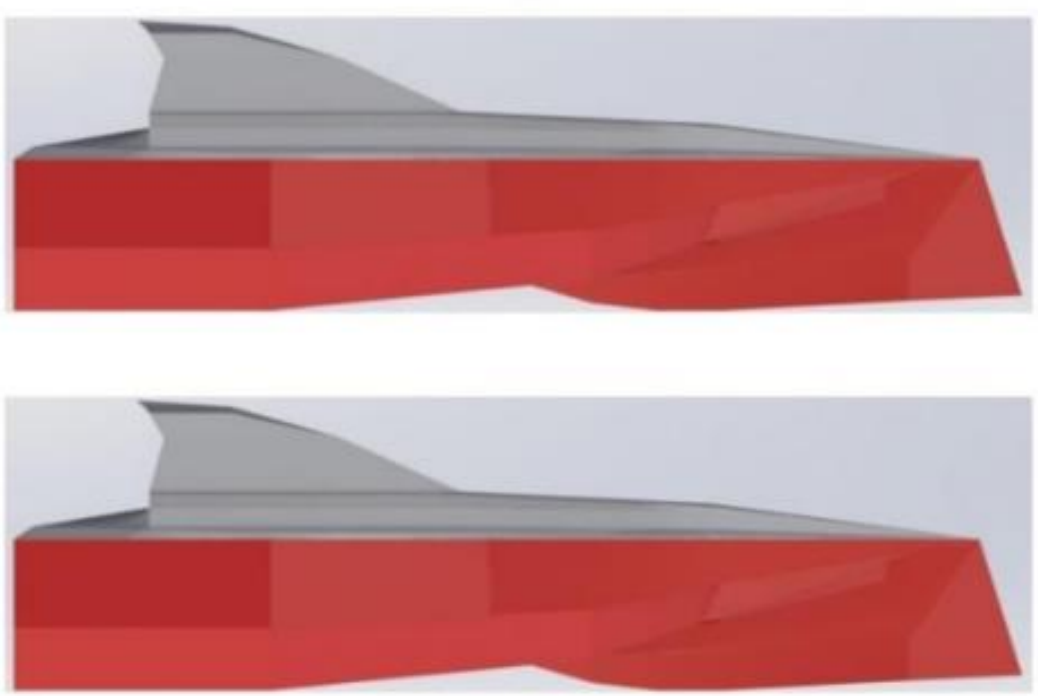

Figure 1 : Modification Catamaran Hull Type on Hybrid Hull Ship

\subsection{Resistance Ship Analysis}

Ship resistance analysis using Maxsurf Resistance, ship resistance analysis using MAxsurf Resistance has been carried out in various ship studies, such as research on finding the most resistant hull form of trimaran type ship [5]. Research on revealing a symmetric trimaran ship prisoner sailing on the surface of a deep and calm ocean [6]. Research on prediction of resistance on catamaran vessels using OpenFOAM [7] and investigating resistance experienced by monohull, catamaran and trimaran vessels [8]. 


\subsection{Calculation Motor Power}

To calculate motor power must be taken into account is Effective Horsepower (EHP), Thrust Horsepower (THP), Delivered HorsePower (DHP), Shaft Horsepower (SHP) and Brake HorsePower (BHP). In simple terms, transfer of power from driving motor to ship lining is shown in Figure 2. Bellow.

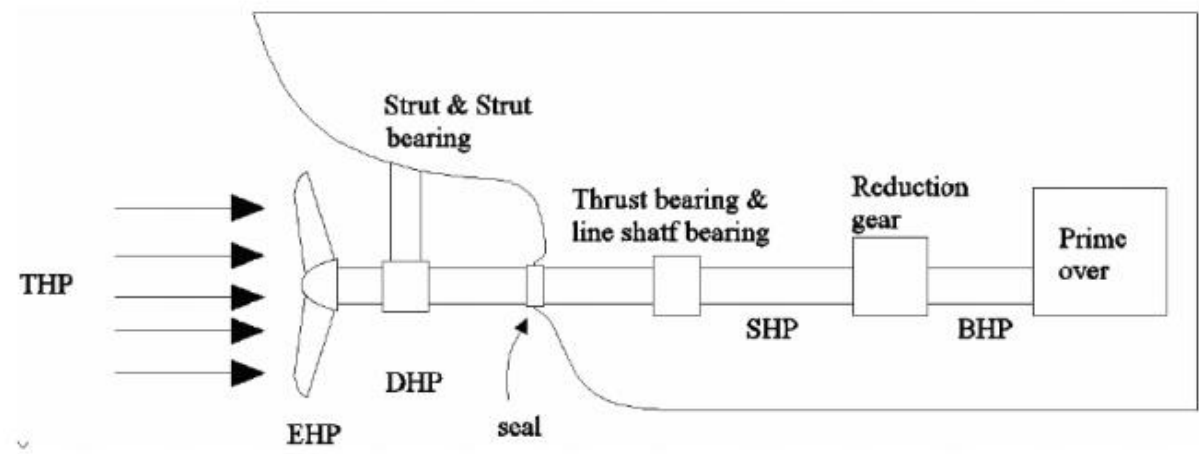

Figure 2 : The Forces Acting on Ship Propulsion System

\section{RESULTS AND DISCUSSION}

\subsection{Ship Resistance}

Ship resistance was analyzed using Maxsurf Resistance to reveal obstacles experienced by three ship models using the Slender Body method with a speed range of 0-6 knots and parameters for calculating ship resistance were adjusted to ITTC (International Towing Tank Conference). Slender Body method choice because this method is used to calculate ship resistance with a lean hull [9]. The analysis results are then compared so that ship design has lowest resistance. Graph of analysis results to see ratio of ship resistance is shown in Figure 3.

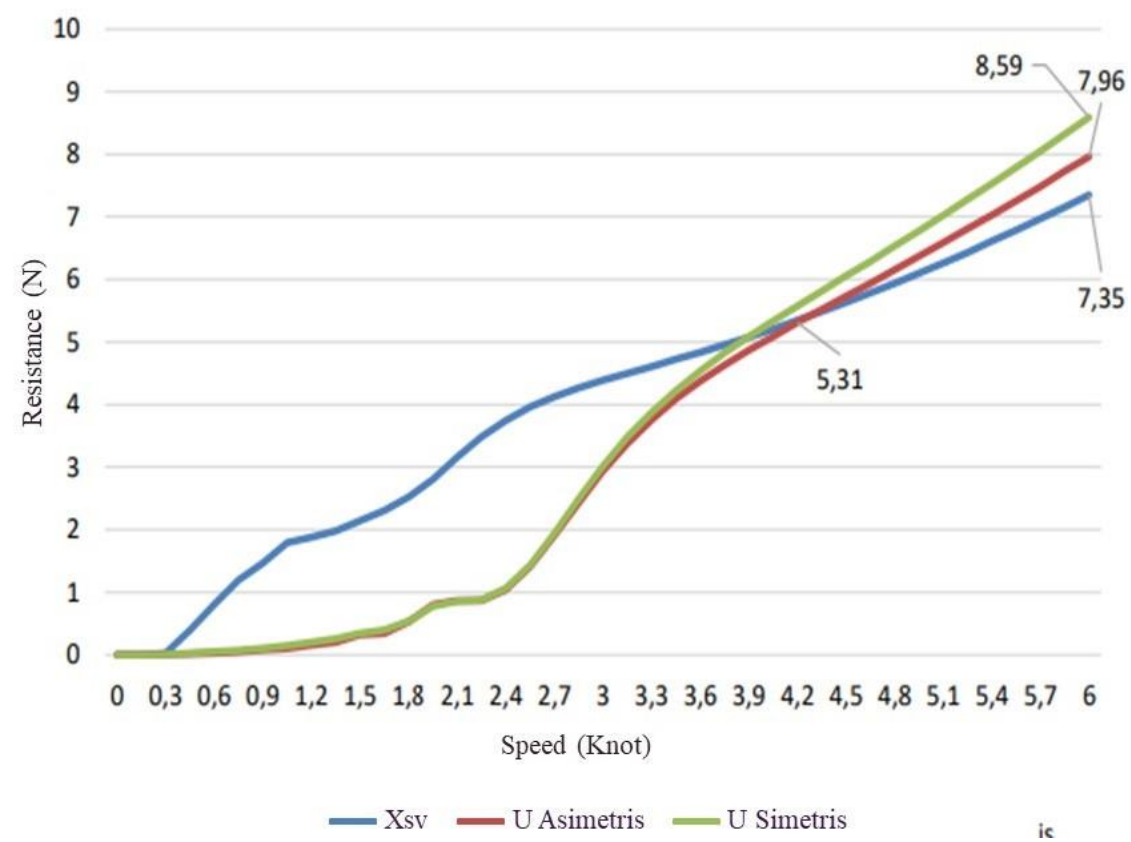

Figure 3 : Graph of Comparison Resistance Experienced by Each Model at Each Ship Speed

Based on analysis result using Maxsurf Resistance with Slender Body method at 6 knots speed, lowest resistance was experienced by $\mathrm{V}$ Asymmetric catamaran hull type $(7.35 \mathrm{~N})$, then on ship with an $\mathrm{U}$ Asymmetric catamaran hull type $(7.96 \mathrm{~N})$ and highest is on a shi[ with U Symmeric catamaran hull type. However, at speed 0-4.2 knots the ship with V Asymmetric catamaran hull type experiences higger resistance from two models. hull type has lowest resistance at speed 0-4.2 knot resistance with $\mathrm{U}$ Asymmetric catamaran hull type. At speed 0-4.2 knot resistance experienced by ship is $5.31 \mathrm{~N}$, while in $\mathrm{V}$ Asymmetric catamaran hull type resistance experienced by ship is $5.35 \mathrm{~N}$. 


\subsection{Motor Power}

\subsubsection{Effective Motor Power}

Based on the analysis result of hull model with Maxsurf Resistance at speed of 6 knot (V), ship model with rear hull uses U Asymmetry hull type, resistance experienced is $0.796 \mathrm{KN}(\mathrm{R})$. calculation effective power of ship is as follows:

$$
\begin{aligned}
& P E=R . V \\
& P E=0.00796 .6 \mathrm{Knot} \\
& P E=0.04776 \mathrm{Kw}
\end{aligned}
$$

\subsubsection{Wake Friction}

Wake Friction (w) is the difference in speed of ship with velocity of water flow to propeller, so that it will produce a coefficient of flow. Ship is designed using a twin-screw propeller, so wake friction value is:

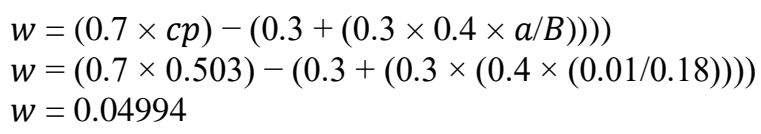

\subsubsection{Thrust Deduction Fraction} follows:

Thrust Deduction Fraction $(\mathrm{t})$ is thrust required to propeller ship. The calculation of $\mathrm{t}$ value is as

$$
\begin{aligned}
& t=k \times w \text { value of } \mathrm{K} \text { is between } 0.7-0.9, \text { taking } \mathrm{k}=0.8 \\
& t=0.8 \times 0.04996 \\
& t=0.03995
\end{aligned}
$$

\subsubsection{Speed of Advance}

Speed of advance (Va) is acceleration water in the propeller section moving less than speed of ship. This is due to presence of hull in front propeller, which changes average it is equal to $3.0864 \mathrm{~m} / \mathrm{s}$. calculation speed of advance as follows:

$$
\begin{aligned}
& V a=(1-w) \times V s \\
& V a=(1-0.04994) \times 3.0864 \\
& V a=2.9322 \mathrm{~m} / \mathrm{s}
\end{aligned}
$$

\subsubsection{Efficiency Relative Rotative}

Value Efficiency Relative Rotative ( $\eta \mathrm{rr}$ ) for twin screw ship between 0.95-1.0, taking 1.0 [9].

\subsubsection{Propulsive Efficiency}

Efisiensi propulsive ( $\eta$ ) is propeller efficiency at time of open water test, value is between $40-70 \%$ and taking $50 \%=0.5[10]$.

\subsubsection{Hull Efficiency}

Hull Efficiency ( $\eta$ hull) is the ratio between effective power and thrust [10]. In gastric efficiency there is no direct unit conversion.

$$
\begin{aligned}
\eta H & =(1-t) /(1-w) \\
\eta H & =(1-0.03995) /(1-0.04996) \\
\eta H & =1.01
\end{aligned}
$$

\subsubsection{Porpulation Coefficient}

Population Coefficient is product of hull efficiency propulsive efficiency and relative-rotation efficiency. Calculation of propulsion coefficient is as follows:

$$
\begin{aligned}
& P c=\eta H \times \eta p \times \eta r r \\
& P c=1.01 \times 0.50 \times 1.0 \\
& P c=0.505
\end{aligned}
$$




\subsubsection{Delivered Horse Power}

Calculation of delivered horsepower (DHP) is as follows:

$$
\begin{aligned}
& D H P=P E / P c \\
& D H P=0.04776 \mathrm{Kw} / 0.505 \\
& D H P=0.09 \mathrm{Kw}
\end{aligned}
$$

\subsubsection{Thrust Horse Power}

Thrush Horse power is power that a propeller sends to water. Calculation is as follows:

$$
\begin{aligned}
& T H P=P E / \eta H \\
& T H P=0.04776 / 1.01 \\
& T H P=0.004728 K w
\end{aligned}
$$

\subsubsection{Calculation of Shaft}

Horse Power (SHP) the motor used to move the ship is placed in the middle, so that mechanical loss that occurs is $3 \% . \eta s \eta b=0.98$ [11].

$$
\begin{aligned}
& S H P=D H P / \eta s \eta b \\
& S H P=0.09 / 0.98 \\
& S H P=0.091 K w
\end{aligned}
$$

\subsubsection{Calculation Power Main Engine}

a. BHP Scr

Ships do not use reduction gears; this is because they use an electric motor so that rotation speed can be controlled.

$$
\text { BHPSCr }=S H P=0.091 K W
$$

b. BHPmcr

the power needed to move ship to reach a service VS $80-85 \%$ of output power driving motor under Continues Service Ranting (CSR) conditions

$$
\begin{aligned}
=B H P S C r & / 0.85 \\
& =0.091 \mathrm{Kw} / 0.85 \\
& =0.1070 \mathrm{KW}
\end{aligned}
$$

\section{CONCLUSION}

Often cases of illegal fishing by foreign fishing ships in Indonesian oceans have become a reference for B-NINE TEAM to design and manufacture ships to guard and monitor Indonesian oceans. Safehaven Marine developed a hybrid monohull and catamaran for ships with high speed and good stability. Therefore, Safehaven Marine ship model becomes a reference in design of hull ship. There are two types of modifications applied, namely U Asymmetric modification and U Symmetric modification. Based on test of ship resistance with computer simulation using Maxsurf Resistance software at speed 6 knot, the lowest resistance was experienced y $\mathrm{V}$ Asymmetric catamaran hull type $(7.35 \mathrm{~N})$, then on ship with an $\mathrm{U}$ Asymmetric catamaran hull type $(7.96 \mathrm{~N})$ and the highest is on ship with U Symmetric catamaran hull type $(8.59 \mathrm{~N})$. However, at speed 0-4.2 knots the ship with V Asymmetric catamaran hull type experiences higher resistance from two models. hull type has lowest resistance at speed 0-4.2 knot resistance with U Asymmetric catamaran hull type. At speed 0-4.2 knot resistance experienced by ship is $5.31 \mathrm{~N}$, while in V Asymmetric catamaran hull type resistance experienced by ship is $5.35 \mathrm{~N}$. Based on calculation of motor power ship is $0.04776 \mathrm{KW}$ and main engine power is $0.1070 \mathrm{KW}$. Based on the test, hull was selected using a hybrid mono-catamaran hull with the rear hull using U Asymmetric catamaran hull with flat inside, front ship using a monohull type with V-type and bow using X-bow type for wave piercing. Process of making a ship model uses fiberglass for material.

\section{REFERENCES}

[1] Santoso, D. dan Nafisah, F. Indonesia's global maritime axis doctrine: Security concerns and recommendations. Jurnal Hubungan Internasional. No.2, pp. 86-98. 2017.

[2] Syahril dan Nabawi, R. A. Numerical Investigation of the Effect on Four Bow Designs Flat Hull Ship. International Journal of GEOMATE. Vol. 17, Issue 62, pp. 231-236. 2019. 
[3] Safehaven Marine. XSV 20. Diakses dari https://www.safehavenmarine.com/xsv20 pada tanggal 05 Juli 2020.

[4] Maxsurf@, Formation Design Systems Pty. Ltd., 2011.

[5] Poundra, G. A. P., Utama, I. K. A. P., Hardianto, D., and Suwasono, D. Optimizing trimaran yacht hull configuration based on resistance and seakeeping criteria. 10th International Conference on Marine Technology. Procedia Engineering, Vol. 194, Issue 2017, pp- 112-119. 2017.

[6] Hafez, K. A. and El-Kot, A. A. Comparative investigation of the stagger variation influence on the hydrodynamic interference of high speed trimaran. Alexandria Engineering Journal, Vol. 51, Issue 2012, pp 153-169, 2012.

[7] Bustos, D. S. H. and Alvarado, R. J. P. Numerical hull resistance calculation of a catamaran using OpenFOEM, Ship Science \& Technology, Vol. 11 Issue 21, pp. 29-39. 2017.

[8] Murdijanto, et al. An investigation into the resistance/powering and seakeeping characteristics of river catamaran and trimaran. Makara Teknologi. Vol. 15, No. 1, pp. 25-30, 2011.

[9] Adietya, B. A., Zakky, A F. and Ramadhan, F. Studi pra perancangan kapal monohull katamaran trimaran di perairan Bali. Kapal. Vol. 10. No. 1. 2013.

[10] Lewis, E. V. Principle of Naval Architecture Vol. II. The society of Naval Architects and Marine Engineers. 1972.

[11] Surya, J. A. Studi Perancangan Sistem Propulsi dan Optimasi Hull Pada Kapal Militer Fast LST (Landing Ship Tank). Skripsi. Institut Sepuluh Nopember Surabaya. 2011. 